\title{
ЗАСОБИ ПСИХОЛОГІЧНОЇ ПІДТРИМКИ СІЛЬСЬКОЇ МОЛОДІ, ЯКА МІГРУВАЛА В МІСТО
}

Розглядаються основні соціально-психологічні засоби підтримки сільської молоді в процесі ії міграції до міста. Обстоюється думка, що переїзд із сільської місцевості до принципово іншого, міського, середовища $є$ складною життєвою ситуацією і може супроводжуватися різного роду дезадаптаційними проявами. Основними деструктивними переживаннями під час міграції можуть бути тривожність, напруженість, розгубленість, безпорадність та песимізм. Обгрунтовується доцільність використання різноманітних напрямів і форм роботи з різними категоріями молодих мігрантів: сільськими старшокласниками на етапі прийняття ними рішення про переїзд, студентами сільського походження та працюючою в місті сільською молоддю. Ефективні засоби мають бути спрямовані на актуалізацію соціальної мобільності сільської молоді, активізацію іiі самосприйняття в новому середовищі, підвищення рівня рефлексії і вироблення вміння ставити життєві цілі з урахуванням реальної соціальної ситуації та досягати їх. Важливим складником адекватної адаптації названо розширення самосвідомості мігранта уміння усвідомлено робити вибір і брати відповідальність за його наслідки, тобто постійно самовдосконалюватись у процесі особистісного розвитку. Основні напрями цієї роботи мають бути пов'язані зі стимуляцією розвитку таких особистісних якостей, як самостійність, відповідальність, інтегрованість, а також керованість пізнавальної та емоційної діяльності. Описано авторську програму соціально-психологічного тренінгу соціально-психологічної адаптації студентів сільського походження до міського середовища, яка має п'ять модулів. Метою запропонованого тренінгу є сприяння психологічній адаптації студентів сільського походження до нового соціального середовища, знаходження оптимальних моделей поведінки в міському середовищі, формування навичок конструктивного спілкування та ефективної взаємодії із жителями міста. Програму апробовано практичними психологами низки закладів вищої освіти, які підтвердили її ефективність і доцільність використання в роботі із студентами сільського походження.

Ключові слова: сільська молодь, міграція, місто, психологічна підтримка, соціально-психологічний тренінг.

Постановка проблеми. Мігруючи із сільської місцевості до міста, молода людина стикається 3 принципово іншою, часто незнайомою, реальністю, що може призводити до виникнення дисонансу між 
внутрішніми прагненнями та очікуваннями і реальною соціальною ситуацією. Молодь сільського походження, яка прагне залишитися в місті, не просто адаптується до умов міського середовища, а намагається інтегруватися до міської спільноти, стати іiі членом, носієм іiї норм i цінностей. Таке входження молодої людини в спільноту, переживання своєї належності до неї має забезпечити почуття внутрішнього комфорту і допомогти уникнути самотності.

Ситуація міграції із села до міста незалежно від рівня мотивації $\epsilon$ досить складною для молодої людини. Нові умови життя, що часто дисонують зі звичним устроєм, висувають до неї нові вимоги. Постає необхідність адаптації молодої людини до нових умов життя, нових цінностей і соціальних норм. Вибір тієї чи іншої адаптаційної стратегії, 3 одного боку, зумовлений психологічними особливостями особи, а 3 другого - визначає напрям подальшого розвитку особистості та можливість ії самоствердження і самореалізації.

Аналіз останніх досліджень $і$ публікаиій. Згідно з результатами досліджень В. О. Чигрина, найактивніше міграція мешканців села до міста, відбувається саме у віці 15-24 роки [7]. Тож найважливішою і наймасовішою групою сільської молоді, яка мігрує до міста, є сільська молодь, яка прагне здобути освіту. Безумовно, вступ до вищого навчального закладу сам по собі є кризовим періодом і спричинює численні прояви дезадаптації серед студентства. Цьому питанню присвячено низку робіт, в яких обгрунтовується доцільність психолого-педагогічного супроводу адаптації першокурсників до навчання в закладах вищої освіти (далі - 3ВО), розроблено тренінги, спрямовані на вирішення цих завдань (О. Д. Кайріс [2], Л. М. Константинова [3], І. В. Сингаївська [4], Н. В. Хазратова [6] та ін.). Для студентів сільського походження ця ситуація ускладнюється ще й необхідністю адаптуватися до нового, міського, середовища, засвоювати правила і норми життя в міському соціумі, оволодівати міським способом життя. Тому процес адаптації сільської молоді, яка приїхала на навчання до міста, не можна розглядати окремо від загальних процесів адаптації студентства до нових умов життя.

У цьому контексті вищі навчальні заклади стають свого роду середовищем, що сприяє входженню частини сільської молоді в міську спільноту і засвоєнню міського способу життя. Саме під час навчання відбувається чи не найперша реальна зустріч молоді сільського походження 3 містом. Важливим аспектом у цьому сенсі вважаємо ресурси та адаптаційні можливості, які надаються їй під час навчання. Особливу роль у цьому процесі відіграє соціально-психологічна служба 3ВО, діяльність якої спрямована на забезпечення умов для повноцінного i гармонійного індивідуального розвитку студентів, формування у них здатності до саморозвитку і самовиховання, сприяння збереженню та 
укріпленню їхнього здоров'я, підвищення адаптивних можливостей студентів та становлення соціально активної особистості [2]. Серед головних напрямів діяльності психологічної служби можна виділити такі: надання психолого-педагогічної і соціальної допомоги студентам, які перебувають у кризовій життєвій ситуації, з метою успішної адаптації до нових умов навчання і життедіяльності; здійснення психологопедагогічних заходів для усунення відхилень у психофізичному та індивідуальному розвитку і поведінці; корекція порушень у спілкуванні, несприятливих форм емоційного реагування і стереотипів поведінки, конфліктних взаємин; проведення психологічних тренінгів для зняття стану тривожності, нервово-психічної напруженості; навчання прийомів релаксації та саморегуляції; відпрацьовування нових прийомів і способів поведінки; подолання емоційних труднощів у період адаптації та формування позитивної життєвої перспективи.

Поряд 3 дидактичною та професійною адаптацією, яку переживають першокурсники [3], важливим є виокремлення соціально-психологічного іiі аспекту, що пов'язаний із засвоєнням нових соціальних норм, встановленням та підтриманням студентом певного соціального статусу в міському середовищі та новому колективі. Тож, на нашу думку, тренінгові заняття із студентами сільського походження, що мають на меті оптимізацію процесу їхньої адаптації в місті, коректно поєднувати із заняттями, спрямованими загалом на адаптацію першокурсників до навчання у вищому навчальному закладі.

Не вирішені раніше частини загальної проблеми. Аналіз наукових досліджень показав, що наукові розвідки більшою мірою зосереджені на соціально-демографічних та економічних наслідках міграції для існування й розвитку села. При цьому особистість мігранта, який постає перед необхідністю адаптації до нових умов життя та пошуку власної ідентичності, залишається поза увагою дослідників. Маловивченими $\epsilon$ психологічні аспекти міграції та пов'язані з нею можливості зміни в структурі ідентичності мігранта. Загалом відчувається брак практичних розробок щодо соціально-психологічної підтримки саме сільських студентів у процесі їхнього входження у нове навчальне і соціальне (міське) середовище.

Mета статmi: огляд основних соціально-психологічних засобів підтримки сільської молоді в процесі ії входження в міське середовище.

Виклад основного матеріалу дослідження. Проблема запобігання дезадаптаційним проявам, що можуть супроводжувати процес входження сільської молоді в міську спільноту, вимагає комплексного та різнопланового аналізу. Ми свідомі того, що питання міграції сільського населення до міста неможливо подолати виключно психологічними засобами підтримки чи корекції уявлень сільської молоді, оптимізації iii внутрішніх ресурсів. До реалізації цих завдань мають долучитися 
фахівці різних галузей. Однак коректна та своєчасна психологічна допомога здатна якщо не істотно полегшити, то принаймні оптимізувати та пом'якшити процеси адаптації молоді сільського походження в міській спільноті шляхом узгодження iї власних ресурсів та очікувань 3 можливостями, які надає місто.

Варто відмітити, що не всі мігранти із сільської місцевості потребують психологічної допомоги. За умови достатнього розвитку соціальної мобільності та вміння використовувати власний внутрішній ресурс людина здатна сама конструктивно долати суперечності й успішно адаптуватися до нового середовища. Однак є численна група молоді, яка потребує якщо не психологічної допомоги, то принаймні підтримки в складній життєвій ситуації, що може виникнути в результаті міграції. Тож наші рекомендації більшою мірою стосуватимуться саме цієї категорії молоді.

На нашу думку, соціально-психологічна підтримка сільської молоді може реалізовуватися в кількох напрямах. По-перше, це просвітницька і психологічна робота серед сільських школярів, а особливо старшокласників, спрямована на усвідомлення ними власних ресурсів і планів, оптимізацію побудови життєвих завдань і можливості їх реалізації, усвідомлення позитивних і негативних рис як сільського, так i міського життя; свідоме зважування та обгрунтований вибір власного життєвого шляху. По-друге, важливо організувати психологічну підтримку молоді сільського походження, яка приїхала в місто здобувати освіту, незалежно від того, має вона намір залишатися в місті назавжди чи планує повернутися в село. Третім і найскладнішим, на нашу думку, 3 погляду організації напрямом роботи можна назвати психологічний супровід сільських мігрантів, які приїхали до міста в пошуку роботи, через брак у них часу, бажання і можливостей для отримання психологічної допомоги.

Варто враховувати, що часто-густо вибір на користь міграції до міста здійснюється сільськими старшокласниками не в результаті власних обмірковувань, а за зразком чи настановами значущих дорослих та однолітків. Серед сільського населення існує глибоке переконання, що місто має комфортні умови життя, силу-силенну можливостей і може суттєво змінити спосіб та якість життя особи. Згідно з такими уявленнями сам факт проживання в місті вже забезпечує кожного комфортними умовами, гарною роботою, нескінченними можливостями, а міграція односельців до міста сприймається як певного роду успіх і досягнення. При цьому абсолютно не важливо, наскільки реальна ситуація відповідає їннім уявленням про життя в місті. Таке ставлення сільського населення, по-перше, детермінує активне переселення молодого покоління в місто, а по-друге, зменшує, а часто й унеможливлює повернення 
мігранта в село, оскільки такий крок буде сприйматися з нерозумінням, а подекуди й з осудом.

Як показали результати нашого дослідження [1], сільські старшокласники мають гіпертрофоване уявлення про переваги міста як бажаного місця проживання та пошуку роботи. Вони часто очевидно переоцінюють ті можливості, які можуть надати їм міське середовище і міський спосіб життя. Враховуючи, що далеко не завжди місто виправдовує сподівання й очікування сільської молоді, що здійснила міграцію, далеко не всім вдається реалізувати власні можливості в повному обсязі; така ситуація може тільки поглиблювати відчуття незадоволеності і внутрішнього дискомфорту. У цьому контексті постає необхідність формування адекватного образу міського і сільського способу життя, їхніх переваг та недоліків, пошуку власного місця в суспільстві, формування зрілої соціальної ідентичності.

Молода людина сільського походження приїздить у місто з уже більш-менш сформованою картиною світу, власними переконаннями i цінностями, які, потрапляючи в нові обставини, мають дорозвинутися або ж змінитися. Новий соціальний статус вимагає від мігранта не лише усвідомлення вже наявних смислів, а й породження нових. Переживання невідповідності між власними можливостями і потребами має призвести до осмислення особою складної ситуації як невідповідності своїх індивідуальних уявлень реальній ситуації.

Вольові зусилля в цьому контексті відіграють значну роль у процесі успішної адаптації сільської молоді в місті та в пошуку свого місця у новому соціальному просторі. Воля особистості як рефлексивний пласт свідомості слугує “функціональним органом” подолання неузгодженості зовнішнього і внутрішнього світу, тому недостатній розвиток вольової сфери може призвести до зламу життєвого задуму та кризи ідентичності.

Неможливість реалізації старої системи потреб та ієрархії цінностей і смислів призводить до тяжких переживань першокурсника, які можуть стати переломними, тобто змінити напрям його розвитку від особистісного зростання до стагнації чи девіації. Невідповідність сформованих раніше уявлень новим умовам проявляється в неможливості реалізувати життєві потреби за допомогою наявних можливостей і викликає низку переживань. У такій ситуації молода людина не може побороти життєву скруту, віднайти нові потреби та сенс життя, а також розвинути в собі нові можливості для реалізації цих потреб. Найбільш типовими проблемами соціально-психологічної адаптації студентів сільського походження можуть бути ілюзорне уявлення про навчання та життя в місті, розмитість життєвих планів і цілей, вузькі соціальні мотиви та невизначеність власної стратегії життєконструювання. 
Ефективність соціальної адаптації студента сільського походження залежить від того, наскільки адекватно він сприймає зовнішній світ і наскільки складними $є$ переживання його внутрішнього світу. Ступінь пристосування до нових умов життя виражається мірою узгодженості його внутрішніх потреб з можливостями їхньої реалізації в конкретній ситуації. Прагнення молодої людини здобути вищу освіту i iï неспроможність здійснити це через зіткнення з непереборними перешкодами ведуть до переживання ситуації як фрустраційної. Житлові і фінансові проблеми, непосильність навчального матеріалу, вади здоров'я, невміння організувати свій час, неприйняття студентською групою, неуспіх серед протилежної статі тощо можуть сприйматися як проблеми, що унеможливлюють самореалізацію та самоствердження в новому соціальному просторі. Оцінка першокурсником перешкод як непереборних призводить до фрустрації як неможливості реалізації мотиву та досягнення поставлених цілей.

Серед причин фрустрації можуть бути як реальні невдачі, так i антиципування несприятливого розвитку подій. Результатом цього переживання стає втрата сенсу і мети, а також дезорганізація продуктивної діяльності. Переживання фрустрації пов'язане з відчуттям загального дискомфорту, тривожності, страху, гніву, що спрямовані як назовні, так і всередину. Надлишкова психічна напруженість у разі фрустрації зумовлюється багатьма чинниками: значущістю ситуації, наявністю досвіду виходу з подібних ситуацій, ригідністю чи мобільністю психічних функціональних структур, які забезпечують діяльність особи.

Складність зовнішнього світу молода людина сільського походження може подолати шляхом удосконалення світу внутрішнього, що убезпечило б її від неуспішної психозахисної поведінки чи то невротизації і спрямувало до продуктивної діяльності. Саме завдяки коректній побудові життєвих завдань та набуттю відповідних навичок особа може протистояти фрустраційним переживанням. Поведінковий тренінг умінь, транзактний аналіз, різноманітні рольові та психологічні ігри можуть допомогти студентам сільського походження вписатися в ритм міського життя, уникнувши при цьому особливих фрустрацій та дезадаптивних проявів.

Деструктивні переживання виявляються найчастіше у вигляді тривожності, напруженості, розгубленості, безпорадності, песимізму тощо. Отож маємо виокремити ці види переживань, з'ясувати умови їх виникнення, запропонувати не лише засоби виходу з критичних ситуацій, а й намітити шляхи і способи розвитку в собі впевненості, оптимізму, зацікавленості тощо. Молода людина сільського походження має досягти зрештою душевної рівноваги і цільової осмисленості свого подальшого життя, а для цього вона повинна за допомогою власних 
переживань перетворити складну ситуацію, що може виникнути внаслідок міграції, з тяжкої і безглуздої в осмислену, привабливу й успішну.

Робота зі студентами сільського походження може зосереджуватися на кількох основних аспектах. Перш за все це подолання конфліктів і непорозумінь у спілкуванні $з$ міськими однолітками, оптимізація взаємодії цих двох груп молоді. По-друге, сприяння адаптації сільської молоді до міського темпу і способу життя, а також аналіз власних планів і перспектив, підтримка в постановці життєвих завдань і побудові життєвих планів.

У цьому контексті можна виділити три основні напрями роботи психологічної служби у вищому навчальному закладі. Перший - забезпечити індивідуальне психологічне консультування для студентства, у тому числі з проблем адаптації до міського середовища. Для цього важливо, щоб психолог володів основною інформацією щодо перебігу адаптаційних процесів у студентів сільського походження, про можливі труднощі, у тому числі і соціально-психологічного плану, з якими може зіткнутися молода людина.

Другий, досить ефективний, напрям - розроблення і впровадження спеціально-психологічних тренінгових програм, спрямованих на актуалізацію соціальної мобільності сільської молоді, активізацію їі самосприйняття в новому середовищі, підвищення рівня рефлексії і вміння ставити життєві цілі з урахуванням реальної соціальної ситуації та досягати їх.

Третім важливим напрямом роботи, на наш погляд, є інтеграція в тренінгові програми, що активізують адаптаційні можливості студентства під час навчання у ВН3, окремих занять, що сприяли б зміцненню дружніх взаємин між сільською і міською молоддю, кращому розумінню ними одне одного.

Отже, йдеться про необхідність формування надалі в сільських старшокласників і студентів сільського походження соціально-професійних і поселенських орієнтацій, спрямованих на свідомий вибір місця проживання і роботи.

Ще однією важливою групою, яка потребує соціально-психологічної підтримки в процесі міграції, є сільська молодь, яка переїхала до міста в пошуках роботи. Чисельність цієї групи молоді (і загалом сільського населення) у великих містах постійно зростає. Складність надання психологічної підтримки цій категорії населення пов'язана перш за все з неможливістю його об'єднання для групових форм роботи, тож чи не єдиним засобом допомоги йому залишається індивідуальне психологічне консультування. До того ж така молодь має на меті пошук роботи і заробляння грошей, а отже, у неї майже не залишається вільного часу і фінансових ресурсів для роботи із психологом. Ще одним осе- 
редком надання психологічної допомоги цій групі молоді можуть стати центри зайнятості, де можна організувати групові тренінги та індивідуальне консультування. На нашу думку, робота в таких групах має бути більшою мірою спрямована не на розуміння переваг і недоліків життя в селі і місті, а на усвідомлення власних ресурсів і рівня їхньої відповідності соціальним очікуванням, а також на засвоєння ефективних технік самодопомоги.

Важливим складником адекватної адаптації є розширення самосвідомості мігранта - його вміння усвідомлено робити вибір і брати відповідальність за його наслідки, тобто постійно самовдосконалюватись у процесі особистісного розвитку. Основні напрями цієї роботи мають бути пов'язані зі стимуляцією розвитку таких особистісних якостей, як самостійність, відповідальність, інтегрованість, а також керованість пізнавальної та емоційної діяльності. Для вдосконалення навичок долання внутрішніх конфліктів доцільно використовувати техніки когнітивної і позитивної психокорекції, рефлексивного тренінгу та організаційно-діяльнісних ігор.

Зняття надлишкової напруженості, стан релаксації, а також здатність до самостійного переборювання невпевненості, страхів і тривог досягаються завдяки аутогенному тренуванню, прогресивно-м'язовій релаксації, поведінковому тренінгу тощо. Психологічна допомога особі, яка переживає кризу ідентичності, передбачає також проведення психологічного консультування, застосування у вигляді тренінгів методів гештальттерапії, логотерапії, медитативної і трансперсональної психокорекції, що може забезпечити позитивні зрушення в самосприйманні та активне формування позитивної ідентичності. Однак варто пам'ятати, що кожне кризове переживання: стрес, фрустрація, внутрішній конфлікт, криза ідентичності, - $є$ глибоко специфічним і через це вимагає окремої стратегї психокорекції і свого набору психотехнік.

Одним 3 найефективніших і найпоширеніших методів роботи 3 профілактики та подолання негативних проявів дезадаптації, у тому числі і сільської молоді в місті, є соціально-психологічний тренінг, що базується на принципах взаємодії, активності учасників, опори на груповий досвід та наявності зворотного зв'язку. У такий спосіб створюється середовище спілкування, яке характеризується відкритістю, взаємодією учасників, рівністю їхніх аргументів, накопиченням спільного досвіду, можливістю отримати відверту інформацію про враження від своєї особистості. Тренінг дає змогу реалізувати необхідні психологічні умови розвитку професійної та особистісної самосвідомості людини, актуалізувати іiі ресурси, змінити їі поведінку, ставлення до світу та інших людей. 3 огляду на методичну універсальність, практичну спрямованість і доступність тренінгу його можна вважати перспективним 
засобом особистісного вдосконалення людини. Інтенсивне інтерактивне навчання під час тренінгу дає змогу протягом короткого терміну опанувати великий обсяг інформації і закріпити отримані знання та вміння на практиці. Соціально-психологічний тренінг $є$ активною формою навчання, в процесі якого учасники мають можливість емоційно пережити в особистому досвіді й інтеріоризувати психологічні знання. Навички відпрацьовуються за допомогою певних прийомів і вправ, рольових ігор, групових дискусій, моделювання ситуацій тощо.

Нами було розроблено й апробовано в низці закладів вищої освіти програму тренінгу соціально-психологічної адаптації студентів сільського походження до міського середовища [1, с. 170-181]. В основу цього тренінгу покладено розуміння соціально-психологічної адаптації, запропоноване К. Роджерсом і Р. Даймонд. Його компонентами є загальний рівень адаптивності, або соціальна гнучкість, прийняття себе, прийняття інших, емоційний комфорт, внутрішній контроль, домінування, реальне сприйняття ситуації або низький рівень ескапізму (див. [5, c. 193-197]). Як показали результати дослідження, процес входження молодої людини сільського походження в міське середовище може супроводжуватися різного роду дезадаптаційними проявами, ускладненнями у формуванні зрілої соціальної ідентичності. На запобігання цим проявам і подолання пов'язаних з ними ускладнень і спрямований наш тренінг [1, с. 150-157]. Завдання спрямовані на активізацію адаптивних можливостей сільської молоді, яка приїхала до міста, щоб здобути освіту, і планує залишитися жити в місті.

Мета тренінгу - сприяння психологічній адаптації студентів сільського походження до нового соціального середовища, знаходження оптимальних моделей поведінки в міському середовищі, формування навичок конструктивного спілкування та ефективної взаємодії із жителями міста.

Програма складається 3 п'яти окремих тематичних, логічно завершених модулів. Запропонований тренінг сприяє адаптації студентів вищих навчальних закладів, які приїхали із сільської місцевості, до міського способу життя, посилює динаміку цього процесу за рахунок його актуалізації та переведення на більш усвідомлюваний рівень.

Завдання тренінгу:

- підвищення рівня саморозуміння студентів та прийняття ними інших на основі зростання самооцінки та розвитку рефлексивних навичок;

- розвиток уявлень про новий соціальний (поселенський) статус;

- формування позитивного ставлення до своїх можливостей, а також уміння долати труднощі, що виникають, і надавати підтримку іншим; - актуалізація життєвих планів щодо самореалізації в різних сферах життя; 
- формування ефективних стратегій соціально-психологічної адаптації в місті;

- засвоєння норм міського способу життя;

- розвиток уміння приймати рішення;

- корекція хибних очікувань і типових ілюзій щодо міського середовища та міського способу життя;

- відпрацювання навичок конструктивної взаємодії з однолітками та знаходження оптимальних моделей поведінки в новому середовищі;

- усвідомлення мотивів власної міграції в місто і прийняття зваженого й відповідального рішення щодо подальшого місця проживання.

Тренінг проводиться серед студентів-першокурсників сільського походження. Програма розрахована на п'ять занять по 1,5 години, що проводяться один раз на тиждень. Програма тренінгу передбачає також виконання учасниками домашніх завдань.

Перший модуль - “Знайомство”, метою якого $є$ створення довірливої атмосфери, налаштування учасників на подальшу роботу, обговорення правил і способів взаємодії у тренінговій групі, виявлення очікувань від тренінгу. Незважаючи на те, що учасники можуть бути студентами однієї академічної групи і вже досить добре знати одне одного, проведення цього модуля допомагає краще пізнати інших, створити довірливу атмосферу і налаштуватися на подальшу роботу.

Важливо на початку і в кінці тренінгу провести попередню i контрольну діагностику рівня соціально-психологічної адаптації студентів. Для цього доцільно використати методику “Соціально-психологічна адаптація” К. Роджерса і Р. Даймонд (див. [5]).

За результатами наших досліджень типовими психологічними проблемами, з якими стикається молодь сільського походження, мігруючи до міста, є:

1) хибні, неадекватні очікування та ілюзорні уявлення щодо умов та способу життя в місті;

2) невизначеність життєвих планів і цілей, загальної життєвої стратегії;

3) передчасна ідентичність, сформована під суттєвим впливом батьків та інших значущих дорослих, несформованість власної позиції;

4) необізнаність 3 поведінковими нормами і стандартами, прийнятими в міському середовищі;

5) “зовнішня” мотивація навчання (наприклад, навчання “для батьків").

Однак для тренера важливо діагностувати актуальні проблеми саме цієї групи і в ході занять зробити акцент та більше зосередитися на подоланні виявлених проблем. 
Під час виконання цього модуля учасники працюють із власними асоціаціями на слова “місто" і “село". У такий спосіб визначаються найбільш типові асоціації, що дає змогу діагностувати міру сформованості уявлень студентів про місто і село, їхню схожість і відмінності, реальність цих уявлень та актуальні проблеми, пов'язані з переїздом до міста. Тренер обов'язково має звернути увагу на низку відмінностей між селом і містом, допомогти учасникам усвідомити, що переїзд до міста вимагає від них засвоєння нового соціального досвіду, уміння долати негативні переживання; а завдання, які будуть виконуватися під час тренінгу, покликані допомогти їм в опануванні таких складних ситуацій.

Мета другого модуля "Прийняття себе" - допомогти учасникам усвідомити власні позитивні і негативні риси, підкреслити власну унікальність; сприяти формуванню позитивної самооцінки та самоприйняттю учасників.

Важливо наголосити, що переїзд до міста дає кожному новий досвід: інколи - позитивний, а інколи - і негативний. Часто такий досвід має як позитивні, так і негативні наслідки, і головне завдання - навчитися визначати позитивні сторони кожної ситуації і долати негативні емоції, якими може супроводжуватися новий досвід.

Вправи, запропоновані в другому модулі, сприяють актуалізації самопізнання та пізнання інших учасників, допомагають усвідомити, які їхні особистісні риси можуть стати в пригоді під час проживання в місті; дають змогу отримати зворотний зв'язок від групи; сприяють розвитку вміння адекватно сприймати себе та інших, глибше розуміти цінність кожної людини, бачити позитивні сторони і можливості кожного. Тренер підкреслює, що не існує людей, які мали б лише позитивні або лише негативні риси. Найкраща людина має свої недоліки, а найгірша - свої достоїнства, при цьому всі хочуть прожити щасливе життя. Для цього потрібно долати свої недоліки і розвивати переваги.

У третьому модулі "Прийняття інших" ми ставимо за мету допомогти учасникам усвідомити відмінності між сільським і міським населенням, формувати конструктивні способи взаємодії з міськими жителями, діагностувати життєву позицію і поведінку учасників.

Четвертий модуль “Мої емоції” має на меті розвивати здатність студентів аналізувати власні емоційні стани; систематизувати уявлення, пов'язані з індивідуальним досвідом подолання негативних емоційних станів; сприяти розвитку емоційної чутливості, уміння розуміти та адекватно сприймати інших людей.

Робота під час $n$ 'ятого модуля “Стратегії поведінки” спрямована на те, щоб навчити студентів вибудовувати реальні життєві плани, приймати зважені рішення та брати відповідальність за їхні наслідки. Кожному з нас доводиться щодня безліч разів приймати рішення - як 
прості, так і складні. У житті трапляються ситуації, коли для того, щоб прийняти правильне рішення, слід усе грунтовно зважити. Відтак тренер за допомогою схеми розтлумачує учасникам п'ять основних етапів прийняття будь-якого рішення. Важливим моментом роботи $\epsilon$ тренування поведінки, незалежної від впливу інших, здатності самостійно приймати рішення в ситуації тиску з боку групи. Наприкінці роботи потрібно проаналізувати можливості застосування набутого досвіду на практиці, підбити підсумки виконаної роботи. Учасникам пропонується звернутися до “чарівної скриньки” і поміркувати, чи справдилися їхні очікування протягом тренінгу, чого вдалося, а чого не вдалося досягти.

Висновки. Запропоновані засоби психологічної підтримки сільської молоді, яка мігрувала в місто, можуть стати основою вдосконалення роботи соціально-психологічних служб, спрямованої на формування адаптивних можливостей молоді. Розглянуті форми роботи можуть слугувати практичним інструментом для роботи як із сільською молоддю, яка вже мігрувала до міста і хоче адаптуватися тут, так і зі студентами сільського походження 1-3-х курсів, які нещодавно переїхали до міста, але планують повернутися в сільську місцевість (зокрема допоможуть іій узгодити свої життєві плани). Коректно і вчасно організована психологічна підтримка молоді сільського походження, яка мігрувала до міста чи має намір це зробити, здатна пом'якшити труднощі соціальнопсихологічної адаптації, допомогти їй краще усвідомити власні життєві орієнтири й успішно інтегруватися в міську спільноту. Таку допомогу слід спрямувати на активізацію внутрішніх ресурсів людини, подолання нею кризової життєвої ситуації, вивченої безпорадності та різних проявів дезадаптації, опанування дієвих засобів самодопомоги.

Перспективу подальших досліджень можуть становити наукові розвідки і практичні розробки соціально-психологічного супроводу входження працюючої молоді сільського походження в міське середовище, напрацювання дієвих механізмів впливу на іiі адаптацію в новому соціальному середовищі.

\section{Лimepamypa}

1. Губеладзе I. Сільська молодь у місті: пошук ідентичності : монографія / Ірина Губеладзе. - Київ : Міленіум, 2015. - 236 с.

2. Kaйріс O. Д. Сучасний стан і тенденції розвитку психологічної служби ВН3 в Україні і за кордоном [Електронний ресурс] / О. Д. Кайріс // Вісник психології і педагогіки : зб. наук. праць / Ін-т психології і соц. педагогіки КМПУ ім. Б. Д. Грінченка; Моск. гуманітар. пед. ін-т. - Київ, Москва, 2010. - Вип. 2. - Режим доступу : http://www.psyh.kiev.ua.

3. Константинова Л. М. Специфіка соціалізації студентів-першокурсників на етапі адаптації до нових умов навчання [Електронний ресурс] / Л. М. Константинова - Режим доступу : http://lib.znaimo.com.ua/docs/323/ index-1020068.html. 
4. Сингаївська I. B. Комунікативний тренінг як засіб адаптації першокурсників до навчання у вищому навчальному закладі [Електронний ресурс] / I. В. Сингаївська // Вісник психології і педагогіки. - Режим доступу : http://www.psyh.kiev.ua/index.php?title=Сингаївська I.B.

5. Фетискин Н. П. Социально-психологическая диагностика развития личности и малых групп / Н. П. Фетискин, В. В. Козлов, Г. М. Мануйлов. - Москва : Изд-во Ин-та Психотерапии, 2002. - 490 с.

6. Хазратова Н. В. Включення студента до соціально-психологічного простору ВН3: типи особистісних проблем та консультативна робота з студентами / Н. В. Хазратова // Практична психологія та соціальна робота. - 2000. № 2. - C. 5-8.

7. Чигрин В. О. Сільська молодь: досвід комплексного соціологічного аналізу : монографія / В. О. Чигрин. - Мелітополь, 2006. - 384 с.

\section{References}

1. Hubeladze, I. (2015). Silska molod u misti: poshuk identychnosti [Rural Youth in City: Search for Identity]. Kyiv: Millenium Publ. (ukr).

2. Kairis, O. D. (2010). Suchasnyi stan i tendentsii rozvytku psykholohichnoi sluzhby VNZ v Ukraini i za kordonom [Current status and tendencies of psychological service in universities in Ukraine and abroad]. Visnyk psykholohii $i$ pedahohiky [Bulletin of psychology and pedagogy], Vol. 2, http://www.psyh. kiev.ua. (ukr).

3. Konstantynova, L. M. Spetsyfika sotsializatsii studentiv-pershokursnykiv na etapi adaptatsii do novykh umov navchannia [Specific of socialization of first graduated students on the stage of adaptation to the new condition of study], http://lib.znaimo.com.ua/docs/323/index-1020068.html. (ukr).

4. Synhaivska, I. V. Kommunikatyvnyi treninh yak zasib adaptatsii pershokursnykiv do navchannia u vyshchomu navchalnomu zakladi [Communicative training as a mean of first-year student adaptation to study in institutions of high education]. Visnyk psykholohii $i$ pedahohiky [Bulletin of psychology and pedagogy], http://www.psyh.kiev.ua/index.php?title=Сингаївська I.B. (ukr).

5. Fetiskin, N. P., Kozlov, V. V., \& Manuilov, G. M. (2002). Sotsialno-psikhologicheskaya diagnostika razvitiya lichnosti $i$ malykh grupp [Social and psychological diagnostic of personal and small group development]. Moscow (rus).

6. Khazratova, N. V. (2000). Vkliuchennia studenta do sotsialno-psykholohichnoho prostoru VNZ: typy osobystisnykh problem ta konsultatyvna robota zi studentamy [Inclusion of student to the social and psychological space of university: types of personal problems and consultative work with students]. Praktychna psykholohiia ta sotsialna robota [Practical Psychology and Social Work], 2, 5-8 (ukr).

7. Chyhryn, V. O. (2006). Silska molod: dosvid sotsiolohichnoho analizu [Rural youth: experience of sociological analysis]. Melitopol (ukr).

\section{Hubeladze I. G. Means of Psychological Support of Rural Youth Migrating to City}

The author considers the main social and psychological meaning of support for rural youth in the process of migration to city. It is substantiated that moving 
from rural to a fundamentally different urban environment is a difficult life situation and it may be accompanied by various kinds of maladaptive manifestations. The main destructive experiences during migration can be anxiety, tension, confusion, helplessness and pessimism. The expediency of using different directions and forms of work with different categories of young migrants is sustained for rural high school students at the stage of their decision on moving, for rural students and rural youth working in the city. Effective means should be aimed on actualizing the social mobility of rural youth, enhancing their self-perception in the new environment, raising the level of reflection and the ability to set life goals in the light of the real social situation and achieve them. An important element for adequate adaptation is increasing of migrant's identity, the ability to deliberately make choices and take responsibility for its consequences, that is, to constantly improve itself in the process of personal development. The main directions of this work should be related to the stimulation of the development of such personal qualities as independence, responsibility, integration, as well as controllability of cognitive and emotional activity. The author's program of social and psychological training of rural students' adaptation to urban environment, which has five modules, is described. The purpose of the training is to promote the psychological adaptation of rural students to a new social environment, finding optimal behavior patterns in urban environment, developing skills for constructive communication and effective interaction with urban residents. This program has been tested by practical psychologists of a number of institutions of higher education, which prove its effectiveness and expediency in using with rural students.

Key words: rural youth, migration, city, psychological support, social and psychological training.

(C) Губеладзе I. Г. 